\title{
Poetic Sensibilities, Humanities, and Wonder: Toward an E/Affective Sociology of Sport
}

\author{
Robert E. Rinehart \\ The following is the Presidential Address given to the North American Society for \\ the Sociology of Sport annual meeting in Ottawa, Ontario, on November 6, 2009. ${ }^{1}$ \\ The poet, using the skills that enable compression, \\ packs a world into a tennis ball. The reader, \\ through attentive reading, unpacks that world \\ in a matter of moments.
}

-Anne McCrary Sullivan, 2005, p. 25

We are fascinated by the unit;

only a unity seems rational to us.

We scorn the senses, because

their information reaches us in bursts.

We scorn the groupings of the world,

and we scorn those of our bodies.

-Michel Serres, 1995 [1982], p. 2

In the academy that we often call the "sociology of sport," rarely do we allow for the existence of poets or even of poetic sensibilities. This may seem to be a strange comment, given that NASSS particularly, and the sociology of sport more generally, are seen as stemming from a proud and mostly-honored tradition of the "social sciences." In this case, the emphasis is on "sciences"- -as opposed to more humanities-oriented discussions of the social. ${ }^{2}$ I plan, initially, to provide a contextualization of how I see we have come to where we are at, so please bear with me through my rehistoricizing, or story-making, of the sociology of sport-for, in my worldview, it is all story-making.

The emphasis on "science" by our forebears is not simply an issue of semantics, an innocent word choice, or an arbitrary choice between two poles of the humanities and of the sciences. Nor is the simplistic binary that I have drawn-between the sciences and the humanities - even partially accurate, though we often look at humanities and the sciences as miles apart theoretically, epistemologically, ontologically. There are many who cross-pollinate, using, for example, multiple

The author is with the Dept. of Sport \& Leisure Studies, University of Waikato, New Zealand. 
methodologies to extract both descriptive and interpretive meanings out of their studies. There are those who encourage us to think with a "sociological imagination," in so many different and changing ways (e.g., Mills, 1959; Thrift, 2008; Walk, 2006). To wit, Mills writes

To limit, in the name of "natural science," the problems upon which we shall work seems to me a curious timidity. ... The classic social analyst has avoided any rigid set of procedures; he [sic] has sought to develop and to use in his work the sociological imagination. (1959, p. 120)

Notice that C. Wright Mills is calling for neither a prescriptive nor a proscriptive answer regarding methodology: rather, he is proposing a more universal opening-up of method, a tendency toward - if he were familiar with the term - a "rhizomatic" approach (cf., Deleuze \& Guattari, 1987), indeed, of worldview, to explore fresh and various ways of apprehending the ever-changing and wondrous world. And, of course, our apprehending and our making of these worlds through writing them into being are themselves active acts of wonder.

But, of course, it is ultimately up to us as individuals to grab the brass ring of imagination in what we do. Often, however, we do not: for example, if a series of poems were submitted, without explanation or "framing," to the Sociology of Sport Journal, the International Review for the Sociology of Sport, or the Journal of Sport and Social Issues - for a non-"special issue" issue-would fiction or poetry be considered? The British journal Qualitative Research in Sport and Exercise may be the exception, but time will tell. Yet, Qualitative Inquiry and the International Review of Qualitative Research, as examples, routinely publish such affect-laden "performances," unapologetically and often without "framing." They encourage open texts with "meaning" that needs to be, like McCrary Sullivan's tennis ball, actively unpacked by an imaginative reader. ${ }^{3}$

It seems to me that scholars whose fundamental unit and terrain are the body and the realm of sensory knowledge and understandings, values and affect, should be in the vanguard of exploratory work where exploration into and dissemination of value and affect are experimental-utilizing methods and lenses such as fiction or poetry. But, with a few exceptions, we really aren't doing this. This is not simply a way or representation; it is also a worldview that captures a manner of thinking, a strategic creativity, a poetic sensibility.

I don't think the problem of a lack of proactive stances in our "areas" of the body, physical culture, and contest as represented by our major journals, is just one of a twenty-year lag of the so-called "sub-discipline" of the sociology of sport behind the "parent disciplines" of, now, sociology, communications, media studies, geography, cultural studies, anthropology — and so forth. Because in those areas, scholars are willingly pushing for innovative ways of thinking and performing, seeking new answers to old questions, posing different questions and finding interesting ways of approaching them. We, on the other hand, have largely become reactive, derivative of those within our so-called parent disciplines rather than innovative and experimental with our admittedly-unique subject areas.

Arguably, our "areas" - that is, the subject matters of the body, of how bodies adjust, resist, normalize, enjoy, grow, mortify, discipline, and present themselves in the presence and absence of other bodies-are rife with possibilities for novel and nuanced, experimental and experiential ways of discovering and uncovering 
of meaning and understanding. We have every opportunity to explore, for example, what Heshusius calls "the tacit and somatic modes of knowing [that] all describe a nondescribable, nonaccountable form of knowing that is crucial and vital" (1994, p. 17). ${ }^{4}$ The expressions - and worldviews - stemming from poetry and poetic sensibilities are one way of approaching deep and vital ways of uncovering what it means to be human; to live our lives into existence; to understand, not simply know; to make sense of and be with the world. ${ }^{5}$

However, we-that is, "social scientists" who study sport-examine, mark, investigate, parse, and even discuss marginalized groups and individuals, but we often do it purposefully, in a very clinical, marginalizing way. By the very act of marking, we ourselves perform the acts of marginalization (cf., Montagu, 1997). We bring marginalization into being. By the very act of parsing, we ourselves objectify the body, tacitly (in some cases) agreeing to the premises of Cartesian dualities, to the limitations that exist when we examine whole and irreducible factors by means of appreciable variables. In a real sense, then, we bring body objectification into being. This is akin to the noncorporeal attribute described by Deleuze and Guattari (1987), ". . . one not representing or referring but intervening in a way; it is a speech act" (p. 96). ${ }^{6}$ By acceding to the very dominant terms and questions of things we study, we instantiate them, we validate them.

It is sometimes ironic that the goals many of us have, to somehow claim and envision a "better" world, however defined, are undermined by the unreflexive values we often bring to the work. I am not saying that we alone create marginalization or objectification, or certainly that we cause such stances to be, but that we work in tandem with other factors to legitimize such things as marginalization or objectification.

We examine class differences by first using, then reinforcing, and finally reifying, the discrete, stratifying categories of class. We also have learned to create simplistic binaries - and sometimes complex explanations, which, when broken down, reduce to simplistic binaries-when life is not so clinical, so discrete, so easily broken down. And we call ourselves-some of us do-social scientists, as if to study anything but these easily-digestible variables is "non-scientific"-which, of course, it is. Or at least it is seen as such in the present historical moment.

But why have we privileged the science model over, for example, the humanities model in our "sociology of sport" discourse?

The antecedents of this move are fairly clear, yet again, complex. They rest in mostly political intentions-yet the dances of scientific and cultural hegemony weave into the story as well. Practically speaking, in order for an organization or academic discipline to thrive during a post-Age of Reason moment, Science, writ large, probably loomed - and, to a majority, still looms - as the most reasonable choice. In fact, in arguing for physical education to be an academic discipline, Franklin Henry (1964) strongly advocated for the primacy of many of the sciences, including exercise physiology, anatomy, psychology, physics - all applied to movement (read: physical education). Thinking women and men would advocate, if money and power and status were the main objects, aligning with a Science model, since so-called "provable" "facts," both in quotations, are easily digested for mass consumption. By reducing complex lived experience down to component and hopefully salient parts, however, we collude with policy makers, among others, to make difficult decisions with simplistic models. We let them off the hook. 
But change sometimes actually occurs from within, and, by advocating a paradigm shift of sorts, I am also advocating for a preliminary and fundamental shift in the way that we see sport, sport studies, the academy, and other matters dear to our collective and individual hearts. For example, the impulse to publish within a 21st Century academic model rates highly the numbers of publications and secondarily the quality of publications. Why is that? Is it as simplistic as that we have become so narrowly defined that we no longer can discern quality from tripe? Or is it that the accountants and academic executives want simply-comparable statistics (which are not comparable, we all know this) so they can make simple, nonchallengeable decisions? Are our ways of writing and disseminating knowledge and understanding merely replicating a Science model of knowledge acquisition? Might there be other, more proactive, ways to recapture the wonder of discovery and the excitement of novel understandings?

Too, grants and funding opportunities-more and more the fourth prong of most North American academics' "duties," along with teaching, research, and service-have been kinder to those in the sciences than to those in the humanities (e.g., Whitson \& Macintosh, 1990; Michaels, 2004; Feder, 2008). One has only to witness the explosion of "health sciences" research in the United States and Canada, and the concomitant explosion of monies for such research, to corroborate the simplistic celebration of "evidence based" research protocols by government policy makers.

This is not just a historical phenomenon. In the European Research Council's first grant competition, held in 2007, grant proposals and monies received for "social and human sciences" lagged far behind that given to "physical sciences and engineering" and "life sciences" (Feder, 2008). Whitson and Macintosh, in 1990, also noted that "graduate study in the new discipline of 'human movement' had first been established in the 1950s, along biomedical lines" (pp. 41-42) in Canada and the U.S. And, while grant monies

... for the humanities increased from \$134-million in 1992 to \$335-million in 2002. . . the overall share of giving for the humanities dwindled slightly over the decade, from 2.5 percent to 2.1 percent of total foundation dollars. (Michaels, 2004, p. 17)

Some of this most recent imbalance was, of course, due to a neo-liberal agenda emphasizing less governmental and more private monies for higher education concerns, but other parts of this continuing trend were due to perceptions. Perceptions that the humanities were still "soft"-softer even than the "soft" sciences. Perceptions that a Robert Mapplethorpe controversial photographic exhibitionRobert Mapplethorpe: The Perfect Moment-was correctly viewed by Senator Jesse Helms as "pornographic" and "obscene" (Levinson, 1990). Perceptions that that which one cannot easily apprehend, digest, categorize, make sense of, locate, and thereby lock away as a "known Truth" is not worthy of interest—or at least of serious, scholarly, scientific interest.

In contrast, John Law talks about valuing the "messiness" of "social science research" in human realms (2004); Nigel Thrift values those affect-laden aspects of everyday lived life (2008); Kathleen Stewart (2005) is fascinated by the wonder of the "state of emergence that animates things cultural"(p. 1027). In my view, scholars studying sport and its related areas should be leading the discussions of affect, body discourse, and complex and transitory relationships. 
For the most part, however-and especially, it seems, in sociology of sport, which derives from both physical education and quantitative sociology - there are still residual traces of this 1960 s dichotomous model of "soft" versus "hard" sciences. In practice, the hierarchical relationship still resonates, in the 21 st Century, even though, as Smith asserts, there is now more recognition that "our closest allies are not physical scientists, but rather those humanities types ... [who] enlarge the social conversation and very often present us with new and different ways to think about lives" (2009, p. 99). The traces of this dominant model for sociology of sport are everywhere, but how did it come into being?

The dominant model of the sociology of sport, deriving from John Loy's 1966 insistence — and, with McPherson and Curtis, the 1989 reiteration - that sport itself was a "structured, goal-oriented, competitive, contest-based, ludic physical activity" (1989, p. 15), was premised on what we used to call a quasi-experimental model of research, itself based on basic premises of science. In fact, under "Defining Basic Terms," McPherson, Curtis, \& Loy (1989) situate their work solidly within the science model:

The concept of science has a meaning for sociologists similar to that held by physicists or biologists. Namely, science is the careful description of the real world and the construction and validation of theories about the real world. In principle the goals of all sciences are the same: to describe and explain through the testing of theories. (p. 5)

As good "scientists," we rarely revisit the foundational premises of the establishment of the sociology of sport. But we do not, after all, subject our "subjects" to rigorous experimental designs - and, with humans, we probably will rarely do such a thing. However, according to Smith (2009), "the overwhelming majority of social researchers [in the first part of the $20^{\text {th }}$ Century] and a significant majority to this day were/are convinced that they are engaged in a science of the social that mirrors the science of the physical" (p. 93).

Politically, to align with science in the mid-1960s, particularly in the United States, was a savvy move. Sputnik, a perception of a "domino effect" in Vietnam, and sport as delivered by the Olympics had all announced the Soviet Union and the United States as competitors for the reaches of space exploration, world dominance, and cultural dominance, respectively. And, it was implied, this so-called "Cold War" mentality was a harbinger of the contest which presumably meant superiority of economic, social, and humane systems. Science-elegant and simple, measurable and reducible-was the Weltansicht, or zeitgeist, of the United States' political, cultural, educational, and policy-making leaders, systems, and policy.

B. H. ["Before Henry"- that is, Franklin Henry (1964)], at least in North America, when "sociology of sport" was not a defined field of inquiry as such, the field of physical education had (w)holistic scholars like Jesse Feiring Williams, Eleanor Metheny, Celeste Ulrich, William Harper, and Donna Mae Miller musing about philosophical issues and body practices. Though they mostly are from different "generations," the continuing connective thread tying them together was that they were, indeed, seeing "the body" as holistic.

For example, in Williams' The Principles of Physical Education, first published in 1927 (and seeing eight editions until 1964), his application of "principles" drew on what he called "well-established facts" based upon the sciences, but it also looked 
at "principles derived from philosophic concepts, [where] less stability can be given" (1964, p. 19). We all should know how Williams' use of principles was applied by Henry in 1964 to delineate between "a profession and a trade [where] the former is guided by principles based upon scientific facts and/or philosophic concepts, while a trade is guided only by rules, methods, and directions" (Williams, p. 19).

Franklin Henry, in 1964, suggested that physical education, broadly writ, was a profession - and he later modified this stance to include the ideas that the profession was made up of subdisciplinary areas, much as the biological sciences were categorized. It was a neat and functional way of encapsulating the temper of the times (e.g., the various competitions between the Soviets and the Americans, the insistence on the infallibility of science) with the slight corrective to the arbitrary Cartesian duality of mind-body by claiming "physical education becomes education through the physical" (Williams, 1964, p. 8) not just of the physical.

But I really don't want to talk about science, or a pseudo-scientific method. As with most dominant rhetorics, they have demonstrated themselves to be limiting, constraining, and exclusionary. Instead, I want to talk about poetry, affect, wonder, and the use of a humanities-based method to imagine what our "sociology of sport" might look like if it hadn't still the residual traces of this science-based model. Where might we be if we could rid ourselves of the scoring brought on by ideas tracing back to Cartesian binaries separating mind and body? In fact, where might our societies be? Envisioning this model is not just a philosophical exercise. Imagination and wonder of this sort also insist that we as a field, and area, become proactive, not reactive, that we become more mindful, and welcome visionaries who can imagine different ways of being from those we currently inhabit. This is akin to Ritzer's call for "liv[ing] a more meaningful life within a society increasingly defined by consumption” (1999, p. 217).

Some scholars are asking questions that are thoughtful, imaginative, and creative. They are using many of the tools that separate humans from other living beings to answer, or at least process, those questions. For example, Anne McCrary Sullivan has long advocated for the "poetic representation of data . . to compress and render accessible the results of some kinds of research" (2004, p. 34). Brady (2005) sees poetry as having "special cachet" within the "heading of 'artful science' . . . because it is body grounded and can be a powerful source of communicating at both a sensuous and an intellectual level" (p. 1004). His compromise idea of "artful science" is driven by his call for a "poetics of place with a conscience" (p. 981).

McCrary Sullivan also calls for a merging of science and art: she sees poetry not as a threatening way of comprehending or apprehending the world, or as a class-based (and therefore exclusionary) form of "high" art, ${ }^{7}$ but more as a process toward deeper understanding for all: "It is intellect infused with intuitive insight and emotional truth. It is intellect embodied" (2004, p. 35). Poetry, like dance, long has been a part of human engagement with the world, as a form of understanding the world, both mythopoetically and realistically.

Scientists - and most of us - already think and explain complex ideas using metaphoric language. For example, the computer is a "brain," the brain is a series of electrical or chemical connections and reactions, the Internet, in Senator Ted Steven's world, is a series of tubes. (Obviously, some metaphors work better than others.) But, to make metaphors "work," we need to supply details, fill in with 
concrete examples, form connections that resonate-and that, too, is the work of a poetic sensibility.

I agree with McCrary Sullivan's basic call for the use of poetry in scholarly research, but I would extend her arguments even further: that this use of poetry, and what she terms "aesthetic vision" (2000, p. 220), should not be limited to the "poetic representation of data." Drawing from Caine and Caine's review of research on the brain, McCrary Sullivan points out that "the human brain is hard wired for perceiving patterns, making meaning" (2005, p. 27). But humans also, I would argue, enjoy a good struggle with complex ideas, striving for patterns but not necessarily getting the answers right away, or sometimes ever. As poet and professor Terry Locke says, “. . . bringing seemingly disparate items together . . . making hunches . . . is at the heart of the aesthetic rage for order, of artistic or literary sense-making ..." (2009).

Meaning-making, in this sense, then, can be that there is no master meaning, no grand narrative-though there is "sense making." This worldview resonates with what postmodernism, poststructuralism, and queer theory alike advocate: as Giffney writes, "Queer discourses touch us, move us and leave us unsettled, troubled, confused" (2009, p. 9). The process of striving for this sense-making marks us, underscores our work, allows our sensory bodies effectively, again, to imagine wondrous worlds.

It may be that poetry like T. S. Eliot's "The Waste Land" or Virginia Woolf's poetic prose novel Orlando are not ever fully understood. But the reading and rereading of them, the poring and puzzling over their convoluted intricacies, gives pleasure and added layers to understandings. This concentrated focus and deep reading may afford insights to what it means to be alive, to live in the world at a particular time in a particular place, and to deeper understandings of ourselves in relationship to others.

When I was a graduate student, it seemed as if some questions were taboo. If you couldn't get clear, definitive "data" on it, it wasn't worth asking. So this line of reasoning would exclude examinations of love, pleasure, and many other abstract concepts that essentially define what it is to be human. I used to joke about measuring degrees of love on a five-point Likert scale. To me, it seems absurd because there are so many more interesting questions to ask, yet sport psychologists and exercise scientists appear continually satisfied with a perceived exertion score of 1-15.

But now, deriving from feminist, queer, performance, auto-ethnography, and critical theories and positions, such scholars as John Law, Nigel Thrift, Noreen Giffney, Sarah Ahmed, Elsbeth Probyn, Kathleen Stewart, Anne McCrary Sullivan, Michel Serres, and many others, are exploring not only ways of asking questions that were once unthinkable in the "social sciences"-those of affect and messiness and wonder and feeling - but also of writing their particular answers into being (e.g., Stewart, 2005; Hartnett \& Engels, 2005; Brady, 1991, 2005; Law, 2004; Ahmed, 1998, 2004; Probyn, 2005; Roy, 1998, 2004; Lambert, 2009; Thrift, 2008; McCrary Sullivan, 2000, 2004, 2005; Serres, 1995a[1982]; 1995b). Some, like Thrift and Law, generally work theoretically, posing questions about what we may gain by looking at the underlying "messiness" of lives and affect; Ahmed and Probyn are delving deeply into emotionality and bodily experiences, informed by queer stances; others, like Stewart, Roy, and McCrary Sullivan, have the developed talent to blend theory with method with rhetorical twist. 


\title{
The Ether: Affective and Affected Bodies
}

\author{
On ether and the ethereal: \\ "It has become helpless and irresponsible and even depraved \\ in our materialist intellectual context \\ to write about something so immaterial, so beyond local knowledge, \\ not to mention so without disciplinary location." \\ —Joe Milutis, 2005, pp. ix-x
}

At the foundational, ontological and metaphysical level underpinning this poetic sensibility, I find John Law and Nigel Thrift's work helpful: they both discuss the whole skin of existence, the sinews and heft of abstract and affective, nonlinear thinking, the guts and marrow of everyday moments of incompletion and process. They are both, in slightly different ways, caught up in coacting with, observing, and imagining objects and processes that are both "complex, diffuse and messy" (Law, 2004, p. 2) and contingencies of, in Thrift's terms, the "art of producing a permanent supplement to the ordinary, a sacrament for the everyday, a hymn to the superfluous" (2008, p. 2).

Law is quite eloquent in his call for opening up significant and abstruse ways of understanding:

Parts of the world are caught in our ethnographies, our histories and our statistics. But other parts are not, or if they are then this is because they have been distorted into clarity. (2004, p. 2)

He goes on to ponder how we might teach ourselves to reapprehend the world differently: "Perhaps we will need to know [the realities of the world] through the hungers, tastes, discomforts, or pains of our bodies" (p. 2). Law calls for an embodied "social science," one that does not replace, but rather supplements, existing methods: one that asks new questions.

\section{The Fire: Feminist and Queer Studies}

Arundhati Roy, Elsbeth Probyn, Sarah Ahmed, and Noreen Giffney have pointed us to innovative explorations of the existential nature of feminist and queer theorizings. Particularly looking at issues of interiority, exteriority, and the emotions, these scholars have opened up new ways of knowing and of apprehending and queering the worldviews of researchers.

There is a terrible beauty in the way Roy writes, both her fictions and her "truths" (1998; 2004). She, like the Kathakali Man she describes,

... tells a story, [and] handles it as he would a child of his own. He teases it. He punishes it. He sends it up like a bubble. He wrestles it to the ground and lets it go again. He laughs at it because he loves it. ... [he] is the most beautiful of men. Because his body is his soul. (1998, p. 219)

Roy's worldview sees in images, hears the world from a wondrous poetic sensibility; she story-tells like the man wrestling with ephemeral, yet tangible, bubbles. In her nonfiction work, Roy uses figurative language and devices to concretize that which is transitory and fleeting: she looks at global power relations at the moment of their happening, rhetorically and with profound effect. 
Elspeth Probyn's (2005) project is to look at specific issues-in one case, shame, drawn from Primo Levi's reconstitution of the Holocaust, but also with echoes and linkages to Michael Warner's (1999) work on the politics of shame and Whitaker's poignant chapter "Should I kill myself?" (2006). Probyn's work on "the blush" is both poetic and philosophical, and her style achieves accurate accessibility and transgressiveness. As well, Sarah Ahmed's work (e.g., 1998; 2004) focuses deeply on things both philosophical and pragmatic. While assiduously working to reframe the terms of arguments about postmodernism and feminism, for example, she has grown to engage herself with subjects in nonobjective ways. She states that "feminist and queer scholars have shown us that emotions 'matter' for politics; emotions show us how power shapes the very surface of bodies as well [as] worlds" (2004, p. 12).

Noreen Giffney writes that "Queer theory exposes in its very figuration the way in which discourse flattens out phenomena in an attempt to make them into palpable, digestible sound bites" $(2009$, p. 8$)$. The woof and weave of queer theorists has explored, intellectually, how emotions and bodily responses resonate in and shape our lives, using the very precepts of this poetic sensibility.

\title{
Air and Water: Poetry and Poetic Sensibilities
}

\author{
We, we as humans, being half gorilla and half God, \\ are not about something; we are something, \\ a rather strange something, in fact, a metaphysical act, \\ a venture of and into that which awaits us.
}

-Miles Richardson, 1998, p. 459

But the intricate melding of form and function comes with those scholars who directly apply this poetic sensibility, whether in poetic form or in poesis, a poetic sensibility that culminates in some forms of creative nonfiction. Those of this third group create writings that are both bodily and interactively pleasurable, and remind me of Laurel Richardson's complaint, years ago, that

... for 30 years, I have yawned my way through numerous supposedly exemplary qualitative studies. Countless numbers of texts have I abandoned half read, half scanned. I'll order a new book with great anticipation . . . only to find the text boring. (1994, pp. 516-17)

Her solution? That writers need to see writing as a method of inquiry-and she recommends fresh metaphors, varied writing formats, and experimental writing (pp. 524-525). I think Stewart, McCrary Sullivan, Serres and others are embodying Richardson's call for a more affect-laden engagement with the reader.

For me, Kathleen Stewart perhaps frames the arguments for exploring "emergent things" best. In talking about her work, she says she wants to "pay attention to the poesis, or creativity, of ordinary things" (2005 p. 1027):

... the writing is also a set of provocations . . . [regarding] moments of legibility and emergence, to moments of impact. . . to models of agency that are far from simple or straightforward, to the vitality or animus of cultural poesis in the jump or surge of affect ... and to the ... moment when things resonate with potential and threat. (p. 1027) 
What a wonderful project, to delve into the moments of everyday life where things are admittedly uncertain and contested; where the magic of ordinary lived life is privileged and noticed, noted and celebrated; where meaning, relationships, and dynamics are demonstrated in such a way that audiences engage with others' lived experiences.

Stewart goes on to talk about the how of her writing. She consciously separates herself from a linear, privileged status, and says that her writing is intended

... not as a trusted guide carefully laying out the perfect links between theoretical categories and the real world but rather as a subject caught in the powerful tension between what can be known and told and what remains obscure or unspeakable but is nonetheless real. (2005, p. 1028, emphasis added)

In other words, her work is neither basic knowledge, nor simply descriptive. It marries form and function in an artistic, creative way to approach, in written form, the sensory and lived experience of the transitory, often covert and unsaid moment.

Stewart writes of " . . . the streets . . . littered with cryptic, half-written signs of personal/public disasters. . . Hungry. Will work for food. God bless you” (2005, p. 1030). Later, her poetic detail captures this clue:

A dollar bill stuck out of a car window gets a quick surge forward from the one with the sign and the heightened, yet unassimilated, affect of a raw contact. "God bless you."

Now we are trudging the rough terrain of bodies and the sensuous accumulation of impacts. (2005, p. 1031)

This kind of prosaic layering, of the sensuous engagement and empathy with one who is homeless, is poetic and telling, and it brings up so much to engage with: the universal singular nature of humanity (cf., Denzin, 1989), the complex sensual details of lived poverty.

In more explicit and truly poetic fashion, McCrary Sullivan (2000) has called for the use of poetry to represent biological knowledge for teachers and learners. She calls one of her poetry sets "An autobiography of attention" since, in it, she is representing biological "data" for teachers and learners to more closely engage with the stuff of marine biology. Here is part of one of her poems ${ }^{8}$ :

\section{Notes from a Marine Biologist's Daughter}

My mother . . .

... digs

for chaetopterus, yellow and orange

worms that look like lace.

She leads me where renilla bloom

purple and white colonial lives, where brittle stars, like moss, cling to stone. She knows where the sea horse wraps its tail and the unseen lives of plankton. (2004, p. 212) 
McCrary Sullivan weaves cycles of life with age-old concerns, and does it poetically. She engages the senses, tries to engage the reader or listener, seeks that they not only gain knowledge, but that they also unpack the poem for deeper understanding. She bricolages ${ }^{9}$ details together, so that, like the underlying islands carrying an archipelago of ideas, the surface details compel the reader to look beneath, to look deeper. She also layers carefully, choosing each word after painstaking thought and multiple angles. As she writes, "... the image is the critical agent ... [,] the concrete, particular detail that is important in its own right and also revelatory of something beyond itself" (2004, p. 35). McCrary Sullivan's is a poetry that is at once poetic, informed, and informing. For example, her use of the word "colonial" as an adjective modifying "renilla" is an interesting commentary on how she views the relationships between forces of nature and human power interactions.

Michel Serres' works, primarily his creative works Angels: A Modern Myth (1995b), and Genesis (1995a [1982]), are likewise filled with poetic puzzles. Writing in prose form, his philosophical works discuss many of the fallacies of rationalism, the socially-constructed natures of both chaos and order, and humans' place within the "noise" that is lived life. He writes,

One writes initially through a wave of music, a groundswell that comes from the background noise, from the whole body, maybe, and maybe from the depths of the world or through the front door, or from our latest loves, carrying its complicated rhythm, its simple beat, its melodic line, a sweet wafting, a broken fall. (1995a [1982], p. 138)

Certainly this is puzzling, this complex marriage of body and gut and soul and disorder, his attempts at capturing the randomness and unpredictability of form. Serres tries to write as one feels and acts, just as stream-of-consciousness novelists tried to portray active thought. His work is asking new, deep, and complex questions about what it means to live and interact in a complex world, with bodies that are imperfect and always becoming.

But how do we enter into these worlds, if we have been trained in a modernist, linear worldview that privileges objectivity, results, ends, and not subjectivity, carpe diem, and process? ${ }^{10}$ How do we ask the questions that are so critical to not only achieving deeper understanding, but also to letting the rest of the world know that our subject areas matter both in good and in hard times?

I might add that "this world," like Baudrillard's musings about ancient cartographers' mappings of "the world" to our lived experience (1994 [1981]), is probably truer to our jumbled, dislocated, disjointed, sometimes overwhelming sensory experiences than the way we sometimes create sense of these experiences. We "sew" together our lives, write them into being, understand them in a variety of ways, and this very push for linearity may itself be a socially-constructed stance stemming from a hegemonic science model and, by extension, from a modernist worldview.

\section{Earth: The Poetic Body}

A few exemplars from sport studies may serve as models for experimental and courageous forms of research-for pushing boundaries, asking deep probing questions about the emergent "moment when things resonate with potential and threat" (Stewart, 2005, p. 1027). I have selected three I am familiar with, but of course, in 
different ways, there are kernels of this appreciation for wonder, this knack of the poetic sensibility, embedded in many of our works (cf., Lambert, 2009). But they aren't being published, except in "special issues," in sport-related journals! The three exemplars are Katie Fitzpatrick's unpublished poem, "Kids I used to know," Synthia Sydnor's “A History of Synchronized Swimming” (1998), and Mike Silk's "Mow my Lawn" (2008).

Fitzpatrick's unpublished poem, "Kids I used to know," is part of her $\mathrm{PhD}$ dissertation. She describes the despair, hopes, and perceived prospects for Pacifika kids in a city environment-and the power relations that constrain and inscribe such prospects. At the risk of doing a disservice to her poem, I quote only two stanzas here ${ }^{11}$ :

\section{Kids I used to know}

... Sometimes I can still see You in my class

writing down the content, filling pages with lines and asking questions

laughing

thinking of getting drunk later that day

in the park

thinking about how your family need you to be a lawyer

And now, I watch You working pizza,

spreading the toppings, taking orders

From everyone

I watch You in my mind holding your baby soft and silent in the morning light, rocking her asleep against your hard chest,

smiling at her tiny fingers waving to catch the sun

glad you decided to leave the gang

Fitzpatrick has, through repetition and telling detail, imagined circumscribed lives, reflected diminishing agency, and portrayed the hope of engagement with an educational system that simply does not engage with marginalized students.

Synthia Sydnor (1998) has grounded her postmodern work in divergence, while adhering to an aesthetic that challenges traditional sport history style and presentation. She provides a deep and idiosyncratic reading of synchronized swimming. In marrying form and function, she writes from a multitude of points of views, of multivocality, that is at once embodied and scholarly. As Sydnor writes, in a selfaware statement on her own so-called "transgressiveness":

... when I heed Benjamin [who encouraged us "to seize hold of a memory as it flashes up in a moment of danger"], please do not react by "policing, punishing, mocking, even ridiculing" (Denzin, Interpretive Ethnography, 251) such an essay as mine as not 'real' history. Do not dismiss my take on synchronized swimming as "postmodern mumbo jumbo" (anonymous reviewer of one of my manuscripts, August 1995). Instead, I want the reader/listener to engage with me and/or many others in disparate "complex subtle arguments" (Norman K. Denzin, Interpretive Ethnography: Ethnographic Practices for the 21st Century. . .). (1998, p. 266) 
Sydnor insists on her right to seek answers to very different, affective and valueladen issues. "A History of Synchronized Swimming" effectively anticipates Thrift, Law, and Stewart's calls to examine the ethereal, the momentary, the transitory. Sydnor's is a courageous stance - and make no mistake, true transgression is often "punished" and disciplined in various ways-especially in terms of the heavily science-laden status-quo of sport studies in the mid 1990s.

The first thing that strikes one about Mike Silk's "Mow my lawn" (2008) is that it departs from his typically-complex scholarly style. In this creative vignettepoem, he has tried to jolt the reader into experiencing the ugly world of xenophobia, misogyny, racism, and class privilege within several sports venues. The class based chants of "Mow my lawn" directed toward Latino/a fans of Panama's national soccer team (p. 477) are juxtaposed with a discussion of a Latina woman as a sex object by two, presumably, non-Latino men. His method - a short exchange of performative slices-reflects well the jumbled, crazy pitch of mixed emotions surrounding diasporic soccer, white privilege, adolescent power plays, and how humans fight to retain dignity in the face of such unexamined hatred and meanness.

\section{Toward a More E/Affective Sociology of Sport: A Conclusion}

If, as we all seem to know cognitively, we reinvent and reinscribe our cultures and world at least every generation, why do we compulsively cling to old patterns of apprehending and presenting the world? These patterns are the ones that say, in hierarchical and vertically-aligned forms, that our insights are the best, that our arguments most persuasive. I think it is a human attempt, a human tendency or foible, toward "regression to the (safe, comfortable) mean." But the key word here is cognitively. We have somehow conflated cognition with rationality, with linearity, and with the hegemony of statistics and statistical mindsets. We have been reactive, not proactive, in our attempts to understand-and know-the worlds we inhabit. Yet, we also, while seeking those safe constancies of known worlds, find ourselves fascinated and sometimes even mesmerized by, to us, the unusual. Those things that pique our interest are the things that we hone in on. We pursue our hunches, and this confidence in our implicit knowledge, sharpened by the details we have learned and studied and memorized, is what makes us quasi-magical beings.

I recently viewed the film "The Diving Bell and the Butterfly." It is a biography about Jean-Dominique Bauby, the former editor of Elle Magazine, who suffered a stroke at age 43 , became totally paralyzed but intellectually sound, and could only communicate by means of blinking one eye. At first, it is told from the nearlyclaustrophobic narrowed lens of the camera, as if it is Bauby's eye.

Bauby goes through very classical stages of "acceptance" of his "locked-in syndrome," and soon, like a modern-day Marcel Proust, learns that his interior world is only constrained by his imagination. While most of us would struggle with inactive muscles, let alone the loss of agency from locked-in syndrome, Bauby painted, with a poetic sensibility, what it was to be human without many of the sensory inputs we usually assume as necessary. In the screenplay, based on the book he wrote by dictating each letter with the signal of his blinking eye stopping each letter in the alphabet, he claims that he can escape the confines of his prison-his diving bell—-through an insight he has had: 
... I've only just realized that there are only two things apart from my eye that aren't paralysed. . . Imagination and memory are the only way 1 can escape my diving bell. (Harwood, 2007, p. 39)

Bauby's sensibilities are aesthetic and poetic; his reliance upon his own inner world to "create" new experiences, to build upon old memories, is the stuff of wonder.

Similarly, our attempts must be, in the spirit of C. Wright Mills' expansive call for shaking up our traditional comfort zones, in the spirit of Arundhati Roy's courageous identifications of specific problems that have global and ethical consequences and results, in the spirit of Michel Serres' poetic and lyrical travels to the realms of order and disorder, to continually seek out the taboo, to gleefully transgress, to ask the most difficult—but profound—questions. To leave our self-imposed—and institutionally-sanctioned-comfort zones. It is not an overstatement to say that we have had the magic trained out of us.

As society and the world change and create new subtleties to old gnawing concerns, we too must adapt—by using our knowledge, yes, but also by using our understanding (cf., Denzin, 1997; Rinehart, 1998) — and creatively apply our own imagination and memory to profound problems that both touch on and are implicit within sport. We should be doing this, but many of us often don't.

I have suggested that one of the reasons we often retreat to a safe, linear, "fact built upon fact" based system of analysis is because we are still ensconced in a scientific system where we gleefully celebrate what we know by concretizing life. We truly imagine-and reify - the metaphor that research is done "brick by brick." This model has invaded both the sciences and the humanities for so long that it is considered an assumption that we rarely challenge. I believe that we, in sport studies broadly writ, have the opportunity to be proactive, not reactive- to have the courage to stretch the boundaries, to ask questions outside of the umbrella of Science, while still adhering to rigors that are simply different, and perhaps more humane, rhetorics.

Of course, the ages-old linear formations are fine for some questions. They are even fine for some answers. But a scientific laboratory is not the world. And fact-based knowledges, while important, are not the same as understanding. "Understanding" is not measurable by others, except in a results-based way. Built upon knowledge, understanding is expert knowledge. Understanding is knowledge plus wisdom; it is knowledge and, not knowledge instead of, a poetic sensibility.

This poetic sensibility is not reducible to some simple binary, such as "soft" versus "hard," or the "sciences" versus the "humanities." But its impact upon decision-making, upon the discordant social disparities that create inequitable conditions, cannot be overestimated: understanding, related to empathy, demystifies the "other" in ways that are a beginning to problem-solving. In addition, a poetic sensibility allows one to see the world creatively and cooperatively, so that those with it seek solutions in concert with others, not the control of others.

We live in the world, the world of messy ideas and ideologies, of competing power bases and structures, of pleasure and unfairness, hostility and kindness. We live in a world that, try as we might, does not provide the crystal-clear, clarifying moment of eureka, but instead is often confusing, embattled, and contested.

We will no doubt get complex, muddy, messy answers, but we will have been brave enough to move the quest for new knowledges and understandings, for new and more equitable ways of being, along their admittedly-contested paths. And for those of us who think that this is not our battle: it is. We inherit the world we invent. 


\section{References}

Ahmed, S. (1998). Differences that matter: Feminist theory and postmodernism. Cambridge, UK: The University of Cambridge Press.

Ahmed, S. (2004). The cultural politics of emotion. Edinburgh: Edinburgh University Press. Baudrillard, J. (1994). Simulacra and simulation (trans., Sheila Faria Glaser). Ann Arbor, MI: The University of Michigan Press.

Brady, I. (1991). Anthropological poetics. Savage, MD: Rowman \& Littlefield.

Brady, I. (2005). Poetics for a planet: Discourse on some problems of being-in-place. In N.K. Denzin \& Y.S. Lincoln (Eds.), The SAGE Handbook of qualitative research (3rd ed., pp. 979-1026). Thousand Oaks, CA: Sage Publications.

Deleuze, G., \& Guattari, F. (2004[1987]). A thousand plateaus: Capitalism and schizophrenia. London: Continuum.

Denzin, N.K. (1989). Interpretive interactionism. Newbury Park, CA: Sage Publications.

Denzin, N.K. (1997). Interpretive ethnography: Ethnographic practices for the 21 st century. Thousand Oaks, CA: Sage Publications.

Denzin, N.K. (2003). Performance ethnography: Critical pedagogy and the politics of culture. Thousand Oaks, CA: Sage Publications.

Feder, T. (2008). New European agency introduces internationally competitive funding for basic research. Physics Today, April, 30-31.

Geertz, C. (1973). The interpretation of culture: Selected essays. New York: Basic Books, Inc.

Giffney, N. (2009). Introduction: The "q” word. In N. Giffney \& M. O'Rourke (Eds.), The Ashgate research companion to queer theory (pp. 1-13). Farnham, UK: Ashgate Publishing.

Hartnett, S.J., \& Engels, J.D. (2005). "Aria in time of war": Investigative poetry and the politics of witnessing. In N.K. Denzin \& Y.S. Lincoln (Eds.), The SAGE handbook of qualitative research (3rd ed., pp. 1043-1067). Thousand Oaks, CA: Sage Publications.

Harwood, R. (2007). The diving bell and the butterfly (adapted screenplay, from JeanDominique Bauby's memoir). http://www.simplyscripts. com/oscar80.html Accessed 28 July 2009.

Henry, F. M. (1964). Physical education: An academic discipline. Journal of Health, Physical Education, and Recreation 35, 32-33, 69.

Heshusius, L. (1994). Freeing ourselves from objectivity: Managing subjectivity or turning toward a participatory mode of consciousness? Educational Researcher, 23(3), 15-22.

Lambert, K. (2009). The 2002 Sydney Gay Games: Re-presenting "lesbian" identities through sporting space. Journal of Lesbian Studies, 13(3), 319-336.

Law, J. (2004). After method: Mess in social science research. London: Routledge.

Levinson, D.A. (1990). Robert Mapplethorpe's extraordinary vision. The Tech (MIT) (31 August), 110(31). http://tech.mit.edu/V110/N31/ mapple.31a.html Accessed 28 July 2009.

Locke, T. (2009). Minding the aesthetic: The place of the literary and other arts in education. University of Waikato (Professorial Address, 21 July 2009).

McCrary Sullivan, A.M. (2000). Voices inside schools-notes from a marine biologist's daughter: on the art and science of attention. Harvard Educational Review, 70(2), 211-227.

McCrary Sullivan, A.M. (2004). Poetry as research: Development of poetic craft and the relations of craft and utility. Journal of Critical Inquiry into Curriculum and Instruction, 5(2), 34-37.

McCrary Sullivan, A.M. (2005). Lessons from the Anhinga Trail: Poetry and teaching. New Directions for Adult and Continuing Education, 2005(107), 23-32.

McPherson, B.D., Curtis, J.E., \& Loy, J.W. (1989). The social significance of sport: An introduction to the sociology of sport. Champaign, IL: Human Kinetics.

Michaels, M. (2004). Grants for the humanities doubled in a decade. Chronicle of Philanthropy, 16(20), 17. 
Mills, C.W. (1959). The sociological imagination. Oxford: Oxford University Press.

Milutis, J. (2005). Ether: The nothing that connects everything. Minneapolis: University of Minnesota Press.

Montagu, A. (1997). Man's most dangerous myth: The fallacy of race (6th ed.). Walnut Creek, CA: AltaMira Press.

Probyn, E. (2005). Blush: Faces of shame. Minneapolis: University of Minnesota Press.

Richardson, L. (1994). Writing: A method of inquiry. In N.K. Denzin \& Y.S. Lincoln (Eds.), Handbook of qualitative research (pp. 516-529). Thousand Oaks, CA: Sage Publications, Inc.

Richardson, M. (1998). Poetics in the field and on the page. Qualitative Inquiry, 4(4), 451-462.

Rinehart, R. (1998). Fictional methods in ethnography: Believability, specks of glass, and Chekhov. Qualitative Inquiry, 4(2), 200-224.

Ritzer, G. (1999). Enchanting a disenchanted world: Revolutionizing the means of consumption. Thousand Oaks, CA: Pine Forge Press.

Roy, A. (1998). The god of small things. New York: HarperCollins Publishers.

Roy, A. (2004). An ordinary person's guide to empire. Cambridge, MA: South End Press.

Serres, M. (1995a). Genesis (trans., Geneviève James \& James Nielson). Ann Arbor, MI: University of Michigan Press.

Serres, M. (1995b). Angels: A modern myth (trans., Francis Cowper). Paris: Flammarion.

Silk, M. L. (2008). Mow my lawn. Cultural Studies $\leftarrow$ Critical Methodologies 8(4), $477-478$.

Smith, J. (2009). Judging research quality: From certainty to contingency. Qualitative Research in Sport and Exercise, 1(2), 91-100.

Stewart, K. (2005). Cultural poesis: The generativity of emergent things. In N.K. Denzin \& Y.S. Lincoln (Eds.), The SAGE handbook of qualitative research (3rd ed., pp. 1027-1042). Thousand Oaks, CA: Sage Publications.

Sydnor, S. (1998). A history of synchronized swimming. Journal of Sport History, 25(2), 252-267.

Thrift, N. (2008). Non-representational theory: Space|politics|affect. London: Routledge.

Walk, S. (2006). Painography, risk voyeurism, and the near-life experience. (Presidential Address, North American Society for the Sociology of Sport, 2 November 2006, Vancouver, BC).

Warner, M. (1999). The trouble with normal: Sex, politics, and the ethics of queer life. Cambridge, MA: Harvard University Press.

Whitaker, B. (2006). Unspeakable love: Gay and lesbian life in the Middle East. London: Saki Books.

Whitson, D.J., \& Macintosh, D. (1990). The scientization of physical education: Discourses of performance. Quest, 42(1), 40-51.

Williams, J.F. (1964). The principles of physical education. Philadelphia: W. B. Saunders.

\section{Notes}

1. Though this paper was intended firstly for a sociology of sport audience, I think the points made also apply to the field of kinesiology, broadly-writ. Thus, I encourage readers to make connections, as McCrary Sullivan (e.g., 2004, 2005) has, between this "poetic sensibility" and their subdiscipline.

2. And even humanities-based discussions-let's say subjectivity itself-are constantly being disciplined and constrained by the dominance of the science model in research, everyday lived life, intellectuality, and understandings (cf., Heshusius, 1994).

3. I am indebted to my colleague Deborah Fraser for pointing out McCrary Sullivan's work. 
4. I am grateful to my friend and colleague Paul Whitinui, who brought Heshusius to my attention.

5. Lous Heshusius (1994), in particular, has written eloquently of what she terms "a participatory mode of consciousness"; I use the term "empathy" to describe a similar "like-feeling" for other beings-Heshusius uses the term "selfother" (p. 17) for this kind of merging.

6. Thanks to Richard Pringle for directing me to Deleuze and Guattari's works.

7. Thanks to Jayne Caudwell for this point, and for many critical readings of the manuscript.

8. McCrary Sullivan's whole poem is below:

\section{Notes from a Marine Biologist's Daughter}

My mother loves the salty mud of estuaries, has no need of charts to know what time low tide will come. She lives by an arithmetic of moon, calculates emergences of mud,

waits for all that crawls there, lays eggs, buries itself in the shallow edges of streamlets and pools. She digs for chaetopterus, yellow and orange worms that look like lace.

She leads me where renilla bloom purple and white colonial lives, where brittle stars, like moss, cling to stone. She knows where the sea horse wraps its tail and the unseen lives of plankton.

My mother walks and sinks into an ooze, centuries of organisms ground to pasty darkness. The sun burns at her shoulders in its slow passage across the sky.

Light waves like pincers in her mud-dark hair. (2004, p. 212)

9. The term bricolage has many meanings in a postmodern, poststructuralist, moment. However, for my purposes, I intend it to draw from the artistic, sociological and philosophical traditions that imply its natures: both reflexive and empowered, complex and multilayered, drawing from multiple traditions, "thick" (c.f., Geertz, 1973), and performative and political (c.f., Denzin, 2003, p. 240).

10. There is an interesting parallel here to how much of western sport is results-driven, how subjectively-scored sports are diminished in so many ways in the popular imaginary, and, of course, how this all relates to the problems of masculinised sport, institutions, and contemporary society.

11. Fitzpatrick's poem (unpublished, permission from the author) in full:

\section{Kids I used to know}

Looking out my window I can see You joining the navy line up with a salute, you're waving at your dad, proud and tough smiling 
In the night I can see You

distressed and 17 you hang

in a garage

and your mother wails

(At the funeral your friend tells me he was thinking of the same

but after this he's changed his mind)

I can see You, entering the shop now, with a knife,

just trying to get enough money for the next round of Everything

Sometimes I can still see You in my class

writing down the content, filling pages with lines and asking

questions

laughing

thinking of getting drunk later that day

in the park

thinking about how your family need you to be a lawyer

And now, I watch You working pizza,

spreading the toppings, taking orders

From everyone

I watch You in my mind holding your baby soft and silent in the morning light,

rocking her asleep against your hard chest,

smiling at her tiny fingers waving to catch the sun

glad you decided to leave the gang

Looking out my window I can see You,

hips swinging your lavalava in the music

hands curled and poised

towards tomorrow 